\title{
Composition of immune complexes and their relation to plasma fibronectin in chronic myeloproliferative disorders
}

\author{
T P BAGLIN, A W SIMPSON, S M PRICE, B J BOUGHTON \\ From the Department of Haematology, Queen Elizabeth Hospital, Edgbaston, Birmingham
}

SUMMARY High concentrations of circulating immune complexes were detected by polyethylene glycol precipitation in 11 of 20 patients with myelofibrosis secondary to chronic myeloproliferative disease. Circulating immune complexes showed a positive correlation with plasma IgG concentrations both in patients and controls. Covariance analysis of the two groups showed significantly increased polyethylene glycol precipitable IgG in patients when adjusted for plasma IgG concentrations, indicating that the patients had significantly increased concentrations of complexed IgG. The immune complexes contained IgG, C3, and fibronectin and were inversely correlated with plasma fibronectin concentrations, suggesting that this major non-specific opsonin is important for the normal clearance of immune complexes. Therapeutic plasmapheresis efficiently removed circulating complexes and produced an increase in plasma fibronectin. This suggests that plasmapheresis may be useful for controlling immune complex mediated complications of these disorders.

Increased concentrations of circulating immune complexes have been shown in primary myelofibrosis by several different methods ${ }^{1-4}$ but their pathophysiological importance remains unclear. ${ }^{12}$ Plasma fibronectin is an opsonin which regulates macrophage phagocytosis of micro-organisms and perhaps immune complexes. ${ }^{5}$ As plasma fibronectin is reduced in some patients with chronic myeloproliferative disorders ${ }^{6}$ we examined whether this is related to the high concentrations of circulating immune complexes. We also undertook a detailed study of the composition of immune complexes in these patients and examined the response to therapeutic plasmapheresis.

\section{Patients and methods}

Twenty patients with chronic myeloproliferative disorders and bone marrow fibrosis on trephine biopsy of the iliac crest were studied. There were five cases of primary myelofibrosis, 14 of polycythaemia vera, and one of essential thrombocythaemia. Sixteen healthy volunteers from the hospital staff served as control subjects.

Serum and plasma anticoagulated with edetic acid

Accepted for publication 18 June 1987 were separated from venous blood samples withis two hours of collection. Fibronectin, fibrinogen, and the third component of complement (C3) were determined by rocket immunoelectrophoresis. All other proteins were measured by radial immunodiffusion using specific antisera (Binding Site Ltd, Birmingham).

Immune complexes were precipitated from serum and plasma using 6000 molecular weight polyethylene glycol ${ }^{78}$ at a final concentration of $2 \%$. Proteins were precipitated at $4^{\circ} \mathrm{C}$ for 18 hours, washed in $2 \%$ polyethylene glycol for 20 minutes, and resuspended in physiological saline. Immune complexes were expressed as $\mathrm{mg} / \mathrm{l}$ of precipitated IgG. All samples were analysed in duplicate and the mean value determined. The mean (SD) percentage difference in 20 samples analysed in duplicate was 14(7). The plasma fibronectin precipitated by polyethylene glycol and the non-precipitable fibronectin remaining in the supernatant were also determined. For some experiments, fibronectin was purified by affinity chromatography. ${ }^{9}$ Sodium dodecyl sulphatepolyacrylamide gel electrophoresis was performed under non-reducing conditions in $6.5 \%$ polyacrylamide gels.

The Mann-Whitney $U$ test, correlation by "least squares fit," and covariance analysis were used to analyse the data. 
Table 1 Details of 20 patients with primary myelofibrosis $(P M F)$, polycythaemia rubra vera $(P R V)$, and essential thrombocythaemia (ET)

\begin{tabular}{|c|c|c|c|c|c|c|c|c|}
\hline Diagnosis & $\begin{array}{l}\text { Age } \\
\text { (years) }\end{array}$ & $\begin{array}{l}\text { Duration } \\
\text { of disease } \\
\text { (months) }\end{array}$ & $\begin{array}{l}\text { Haemoglobin } \\
(\mathrm{g} / \mathrm{dl})\end{array}$ & $\begin{array}{l}\text { Neutrophil } \\
\text { count } \\
\left(\times 10^{9} / l\right) \\
\end{array}$ & $\begin{array}{l}\text { Platelet } \\
\text { count } \\
\left(\times 10^{9} / \mathrm{l}\right) \\
\end{array}$ & $\begin{array}{l}\text { Spleen } \\
(\mathrm{cm})\end{array}$ & $\begin{array}{l}\text { Polyethylene } \\
\text { glycol IgG } \\
\text { (mg/l) }\end{array}$ & $\begin{array}{l}\text { Chemotherapy } \\
\text { in previous } \\
\text { three months }\end{array}$ \\
\hline $\begin{array}{l}\text { PMF } \\
\text { PMF } \\
\text { PMF } \\
\text { PMF } \\
\text { PMF }\end{array}$ & $\begin{array}{l}80 \\
66 \\
49 \\
61 \\
51\end{array}$ & $\begin{array}{r}1 \\
1 \\
28 \\
37 \\
35\end{array}$ & $\begin{array}{l}8 \cdot 5 \\
10 \\
12 \\
10 \cdot 5 \\
15\end{array}$ & $\begin{array}{r}11.0 \\
1.5 \\
2.0 \\
3.0 \\
4.5\end{array}$ & $\begin{array}{l}175 \\
200 \\
200 \\
150 \\
400\end{array}$ & $\begin{array}{r}7 \\
10 \\
12 \\
14 \\
1\end{array}$ & $\begin{array}{l}968 \\
786 \\
512 \\
492 \\
412\end{array}$ & $\begin{array}{l}\text { No } \\
\text { No } \\
\text { No } \\
\text { No } \\
\text { No }\end{array}$ \\
\hline $\begin{array}{l}\text { PRV } \\
\text { PRV } \\
\text { PRV } \\
\text { PRV } \\
\text { PRV } \\
\text { PRV } \\
\text { PRV } \\
\text { PRV } \\
\text { PRV } \\
\text { PRV } \\
\text { PRV } \\
\text { PRV } \\
\text { PRV } \\
\text { PRV }\end{array}$ & $\begin{array}{l}70 \\
48 \\
64 \\
66 \\
69 \\
61 \\
63 \\
40 \\
60 \\
65 \\
67 \\
63 \\
55 \\
75\end{array}$ & $\begin{array}{r}74 \\
48 \\
37 \\
20 \\
30 \\
60 \\
20 \\
43 \\
126 \\
68 \\
71 \\
3 \\
51 \\
16\end{array}$ & $\begin{array}{l}14 \\
14 \\
16 \\
14 \\
15 \\
14 \\
14 \\
11 \\
15 \\
14 \\
12 \\
12 \\
14 \\
14\end{array}$ & $\begin{array}{r}17 \cdot 0 \\
10 \cdot 0 \\
5.0 \\
9.0 \\
4.5 \\
30.0 \\
5.0 \\
5.5 \\
4 \cdot 0 \\
7.0 \\
2.0 \\
4 \cdot 0 \\
7 \cdot 5 \\
3.5\end{array}$ & $\begin{array}{r}500 \\
200 \\
200 \\
1000 \\
200 \\
200 \\
600 \\
400 \\
300 \\
450 \\
100 \\
500 \\
400 \\
200\end{array}$ & $\begin{array}{r}4 \\
11 \\
0 \\
0 \\
0 \\
0 \\
3 \\
0 \\
0 \\
0 \\
2 \\
0 \\
3 \\
0\end{array}$ & $\begin{array}{l}800 \\
760 \\
672 \\
648 \\
648 \\
626 \\
573 \\
492 \\
440 \\
376 \\
368 \\
348 \\
296 \\
261\end{array}$ & $\begin{array}{l}\text { No } \\
\text { Yes } \\
\text { No } \\
\text { Yes } \\
\text { Yes } \\
\text { No } \\
\text { No } \\
\text { No } \\
\text { No } \\
\text { No } \\
\text { No } \\
\text { Yes } \\
\text { No } \\
\text { No }\end{array}$ \\
\hline ET & 75 & 13 & 14 & 3.0 & 300 & 0 & 672 & No \\
\hline
\end{tabular}

Two patients each underwent three therapeutic exchanges of plasma on alternate days on a Hemonetics 30 cell processor to determine the effect of removing immune complexes on plasma fibronectin concentrations. A total of 4 litres of plasma from each patient was exchanged with $4.5 \%$ albumin (Blood Products Laboratory, Elstree, England).

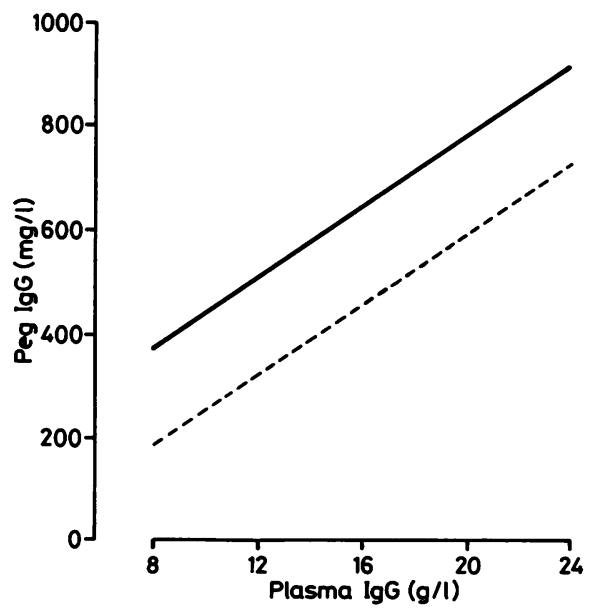

Fig 1 Lines of regression from covariance analysis of polyethylene glycol (PEG) IgG and plasma IgG in 20 patients - PEG IgG $(\mathrm{mg} / \mathrm{l})=34.4 \times$ plasma $\operatorname{Ig} G(\mathrm{~g} / \mathrm{l})+107 \cdot 2$; and 16 controls---: $P E G$ $\operatorname{Ig} G(\mathrm{mg} / \mathrm{l})=34.4 \times$ plasma $\operatorname{Ig} G(\mathrm{~g} / \mathrm{l})-80 \cdot 4$. The difference between the two groups, adjusted for the covariate, was highly significant $(t=4.75, p<0.001)$.

\section{Results}

The clinical features, haematological variables, and concentrations of immune complexes (polyethylene glycol IgG) in 20 patients are shown in table 1 . Concentrations of immune complexes did not increase with age or duration of disease and were constant in stable patients on no treatment: 24 measurements made in seven patients over nine months showed a variation of $10.5(7) \%$ (mean + SD). Three patients with primary myelofibrosis, however, showed two to threefold increases in concentrations of immune complexes during the terminal phase of their disease. Immune complex values did not correlate with spleen size or peripheral blood counts or with myelosuppressive chemotherapy over the preceding three months.

The normal range for plasma immune complex concentrations in 16 control subjects (mean $\pm 2 \mathrm{SD}$ ) was 103 to $507 \mathrm{mg} / \mathrm{l}$ of polyethylene glycol precipitable IgG. Values higher than this were found in three of five patients with primary myelofibrosis, seven of 14 with polycythaemia rubra vera, and one with essential thrombocythaemia. Immune complexes and plasma IgG concentrations showed a significant positive correlation both in patients $(r=0.77$, $\mathrm{p}<0.001)$ and controls $(\mathrm{r}=0.68, \mathrm{p}<0.01)$. Plasma IgG concentrations were $13 \cdot 1(4 \cdot 1) \mathrm{g} / 1$ and $11 \cdot 9(2 \cdot 5)$ $\mathrm{g} / \mathrm{l}$, respectively. Polyethylene glycol precipitable $\mathrm{IgG}$ expressed as a percentage of the plasma IgG concentration was, however, significantly greater in patients compared with that in normal subjects $(4.3 \% v 2.6 \%$, $\mathrm{p}<0.001)$. Covariance analysis of controls and 
Table 2 Percentage precipitation of plasma proteins by 2 polyethylene glycol

\begin{tabular}{llll}
\hline & Patients & Controls & p Value \\
\hline Fibronectin & 79.0 & 67.0 & $<0.02$ \\
IgG & 4.3 & 2.6 & $<0.001$ \\
C3 & 2.4 & 0.7 & $<0.01$ \\
IgM & 3.4 & 3.1 & NS \\
Fibrinogen & 1.9 & 2.0 & NS \\
a -macroglobulin & 1.2 & 1.3 & NS \\
Haptoglobin & 0.9 & 0.6 & NS \\
Albumin & 1.2 & 0.9 & NS \\
\hline
\end{tabular}

patients showed significantly increased polyethylene glycol precipitable IgG when adjusted for plasma IgG $(t=4.75, \mathrm{p}<0.001)$ (fig 1). These results show that when a correction was made for plasma IgG concentrations, all the patients had significantly increased immune complex concentrations.

Sodium dodecyl sulphate-polyacrylamide gel electrophoresis of plasma polyethylene glycol precipitates showed up to nine protein bands. Table 2 compares the percentage of polyethylene glycol precipitation of the four opsonic proteins fibronectin IgG, C3, and IgM with the four non-opsonic proteins fibrinogen, $\alpha_{2}$ macroglobulin, haptoglobin, and albumin. The opsonic proteins all showed high polyethylene glycol precipitability compared with non-opsonic proteins, and up to $79 \%$ of patients' plasma fibronectin was polyethylene glycol precipitated in these experiments. Polyethylene glycol precipitable fibronectin, IgG, and C3 were significantly higher in patients than control subjects and precipitable IgG and C3 showed a significant positive correlation $(r=0.6, p<0.005)$.

The precipitation of the opsonic proteins fibronectin, IgG, and C3 was significantly higher in plasma than in serum; $79 \% \vee 21 \%$ for fibronectin,

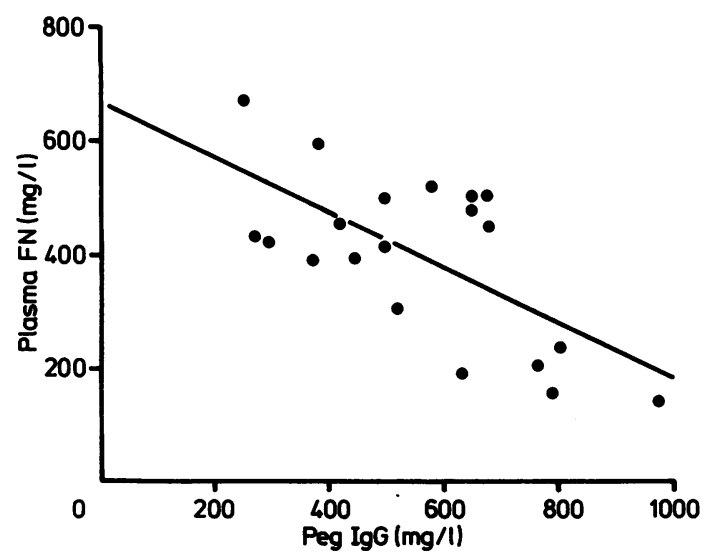

Fig 2 Correlation between concentrations of circulating immune complexes and plasma fibronectin in 20 patients $(r=-0.63, p<0.001)$.
$4.3 \% v 1.6 \%$ for $\mathrm{IgG}$, and $2.4 \% v 0.4 \%$ for $\mathrm{C} 3$ $(\mathrm{p}<0.001)$.

When plasma fibronectin was purified by sepharose-gelatin affinity chromatography its polyethylene glycol precipitability fell from $70 \%$ to $1 \%$. These results and the detection of multiple opsonic proteins in the polyethylene glycol precipitates from plasma suggest that fibronectin is polyethylene glycol precipitated because of the formation of complexes with other plasma proteins.

The normal mean (SD) range for edetic acid anticoagulated plasma fibronectin was $319-795 \mathrm{mg} / \mathrm{l} \mathrm{com-}$ pared with a mean of $557 \mathrm{mg} / \mathrm{l}$ in controls; patients had significantly lower concentrations (mean 404 $\mathrm{mg} / \mathrm{l}, \mathrm{p}<0.001$ ). In patients plasma fibronectin concentrations showed a significant inverse correlation with those of immune complexes $(r=-0.63$, $\mathrm{p}<0.001$ ) (fig 2).

The plasma fibronectin not precipitated by $2 \%$ polyethylene glycol may be viewed as free fibronectin not incorporated into immune complexes. This was significantly lower in patients with high concentrations of immune complexes (mean $42 \mathrm{mg} / \mathrm{l}$ ) compared either with controls (mean $190 \mathrm{mg} / \mathrm{l}$ ) or with patients with low concentrations of immune complexes (mean $137 \mathrm{mg} / \mathrm{l}, \mathrm{p}<0.001$ ).

Plasmapheresis reduced circulating concentrations of immune complexes from $640 \mathrm{mg} / 1$ to $204 \mathrm{mg} / \mathrm{l}$ in one patient and from $584 \mathrm{mg} / \mathrm{l}$ to $159 \mathrm{mg} / \mathrm{l}$ in the second. Non-precipitable fibronectin concentrations rose from 21 to $157 \mathrm{mg} / \mathrm{l}$ and 68 to $123 \mathrm{mg} / \mathrm{l}$, respectively (normal $>100 \mathrm{mg} / \mathrm{l}$ ). Total fibronectin rose from 258 to $433 \mathrm{mg} / \mathrm{l}$ in the first patient and remained at $290 \mathrm{mg} / \mathrm{l}$ in the second.

\section{Discussion}

Immune complexes are activators of the platelet release reaction, ${ }^{10}$ and the release of platelet derived growth factors by this mechanism may be an important stimulus to bone marrow fibroblasts in patients with myelofibrosis. ${ }^{2}$ We observed high concentrations of immune complexes in 11 of 20 patients with myelofibrosis due to various chronic myeloproliferative disorders. When the polyethylene glycol precipitable IgG was adjusted for plasma IgG concentrations the result suggested that increased concentrations of circulating immune complexes were present in all 20 patients. These are important observations if the immune complex theory of myelofibrosis ${ }^{2}$ is to remain tenable.

Plasma fibronectin concentrations are significantly reduced in patients with myeloproliferative disorders, ${ }^{6}$ but the relation between immune complexes and fibronectin concentrations has not previously been determined. Clearance of immune complexes by 
the fixed macrophage system may depend on effective opsonisation, and fibronectin is the major opsonin which regulates macrophage function. ${ }^{5}$ In the presence of effective concentrations of opsonic fibronectin the clearance of immune complexes could prevent complex concentrations from rising, but if immune complex formation were to exceed fibronectin production, an accumulation of complexes might ensue. The negative correlation between immune complex concentrations and plasma fibronectin, and the restoration of total and non-precipitable plasma fibronectin concentrations following removal of immune complexes by plasmapheresis support this hypothesis. Plasma exchange was performed with $4.5 \%$ albumin which contains no fibronectin, and so the recovery of plasma fibronectin concentrations cannot be attributed to therapeutic replacement.

All patients were free from infection at the time of study and only one had biochemical evidence of liver dysfunction, but this patient did not have raised concentrations of immune complex, and plasma fibronectin was normal. Fibronectin depletion and high concentrations of immune complexes were therefore not a result of either infection or impaired liver function.

Using a fixed concentration of polyethylene glycol, protein precipitation by polyethylene glycol is proportionate to the protein concentration and to the molecular weight of the protein. ${ }^{8}$ If, therefore, protein precipitation is expressed as a percentage of the initial protein concentration increased polyethylene glycol precipitation is determined by the molecular weight of the protein and its formation of high molecular weight complexes with other proteins. ${ }^{7}$ With $2 \%$ polyethylene glycol, we found that the percentage precipitation of non-opsonic proteins was minimal in both patients and controls. The increased precipitation of IgM was in keeping with its high molecular weight; the pronounced precipitation of the low molecular weight opsonic proteins fibronectin, $\mathrm{IgG}$, and $\mathrm{C} 3$ was significantly higher in patients, and was most likely explained by the formation of high molecular weight complexes with other proteins.

The high precipitation of fibronectin in the presence of other plasma proteins compared with the isolated protein is also strong evidence in favour of complex formation. Fibronectin will form cryoprecipitable complexes with fibrinogen at $-20^{\circ} \mathrm{C}$ but not in the $4^{\circ} \mathrm{C}$ to $22^{\circ} \mathrm{C}$ temperature range that we used. The minimal precipitation of fibrinogen and the much higher precipitation of fibronectin are strong evidence against this mechanism of polyethylene glycol precipitation of fibronectin. Furthermore, precipitation of fibronectin from serum that contained complexed IgG and $\mathrm{C} 3$ but no fibrinogen was also high.

As fibronectin is bound to fibrin during clot formation $^{11}$ the lower concentrations of immune complexes which we found in serum compared with those in plasma may be explained by incorporation of opsonised immune complexes into the fibrin clot.

TP Baglin is a Leukaemia Research Fund Fellow. The work was partially supported by the United Birmingham Hospitals' Trust Fund. We are grateful to Dr Alan Girling of the department of mathematics, University of Birmingham, for performing the covariance analysis.

\section{References}

i Lewis CM, Pegrum GD. Immune complexes in myelofibrosis: a possible guide to management. Br J Haematol 1978;39:233-9.

2 Caligaris Cappio F. Vigliani R, Novarino A, Camussi G, Campana $\mathrm{D}$, Gavosto $\mathrm{F}$. Idiopathic myelofibrosis: a possible role for immune complexes in the pathogenesis of bone marrow fibrosis. Br J Haematol 1981;49:17-21.

3 Gordon BR, Coleman M, Kohen P, Day NK. Immunologic abnormalities in myelofibrosis with activation of the complement system. Blood 1981;58:904-10.

4 Vellenga E, Mulder NH, The TH, Nioweg HO. A study of the cellular and humoral immune response in patients with myelofibrosis. Clin Lab Haematol 1982;4:239-46.

5 Simpson AW, Boughton BJ. Fibronectin as an opsonic regulator of monocyte phagocytosis. J Clin Pathol 1984;37:787-9.

6 Norfolk DR, Bowen M, Roberts BE, Child JA. Plasma fibronectin in myeloproliferative disorders and chronic granulocytic leukaemia. Br J Haematol 1983;55:319-24.

7 Creighton WD, Lambert PH, Miescher PA. Detection of antibodies and soluble antigen-antibody complexes by precipitation with polyethylene glycol. J Immunol 1973:111:1219-27.

8 Zubler RH, Perrin LH, Creighton WD, Lambert PH. Use of polyethylene glycol (PEG) to concentrate immune complexes from serum or plasma samples. Ann Rheum Dis 1977;36(Suppl):23-5.

9 Vuento N, Vaheri A. Purification of fibronectin from human plasma by affinity chromatography under non-denaturing conditions. Biochem J 1979;183:331-7.

10 Pfueller SL, Luscher EF. The effects of immune complexes on blood platelets and their relationship to complement activation. Immunochemistry 1972;9:1151-65.

11 Mosesson MU, Unfleet RA. The cold insoluble globulin of human plasma. I. purification, primary characterisation, and relationship to fibrinogen and other cold insoluble fraction components. J Biol Chem 1970;245:5728-36.

Requests for reprints to: Dr TP Baglin, Department of Haematology, Queen Elizabeth Hospital, Edgbaston, Birmingham B152TH. 